\title{
学会賞受賞講演
}

\section{Flow of Non-Newtonian Fluids}

\author{
by \\ Yukio TOMITA \\ Faculty of Science and Technology, Science University of \\ Tokyo, 2641 Yamazaki, Noda, Chiba 278
}

\section{非ニュートン 流 体 の 流動}

富田幸 雄*

（原稿受理：1987年9月3日）

\section{1. はじめに}

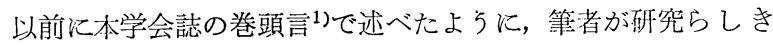
ことを始めたのは1951年からであり，最初は相似則を利用しての 浅底水流による高速気流の研究であった。研究テーマをレオロジ 一関係に変えたのは1957年頃で，それもレオロジーのことは何も 知らないで闇雲に始めたといら状態であった。 それから30年，レ オロジー関係の他, 種々の流体力学に関する研究も行って来たが， 筆者の能力不足が原因して，研究期間の最も長いレオロジー関係 についてもまとまった成果は挙がらなかったと思う。それが今回、 はからずも受賞の栄に浴したのは, 優れた先輩, 共同研究者の賜 物によること極めて大きく，心より感謝申し上げる．以下に筆者 の行ってきたレオロジーに関係する研究の概要を述べる.

\section{2. 非ニュートン粘性流体の流れ}

1955年当時は非ニュートン流体の流れの相似則については, 类 だ余り組織的な研究が進しでいなかった。伊藤四郎氏（現東京工 業大学名誉教授）は, Bingham 流体の流れの研究2)に括いて, 見 掛け相似の法則という與味ある提案を行った. 自由表面のない幾 何学的に相似な境界のまわりの Bingham 流体の二つの流れが相 似になるためには，

$R e=\frac{\text { 惯性力 }}{\text { 粘性力 }}:$ Reynolds 数, $N_{\mathrm{B}}=\frac{\text { 降伏力 }}{\text { 粘性力 }}$ : Bingham 数

なる二つの無次元数が，それぞれ同時に等しくなればよい．乙か 乙，この上5にすると実験の手数が多くかかり，かつ一般的に見 通しが惡くなる，そこで伊藤はこれを， $R e^{*}=\frac{\text { 単位時間に一定の境界内に入る全運動エネルギーの代表量 }}{\text { 単位時間に失われるエネルギーの代表量 }}$

\footnotetext{
* 東京理科大学理工学部 $\overline{\mathbf{T} 278}$ 野田市山崎 2641
}

という一つの無次元数によって, 工学的に重要な管内流れの圧力 損失や攪汼動力の問題を処理するという, いわゆる見掛讨相似の 法則を提案した。筆者はこの問題に興味を持ち, 異なった角度か ら検討した結果, 管内流れに执いては, 層流, 乱流を通じて圧力 損失を一つの無次元数で整理するという見掛け相似の法則は，敩 密な意味での成立が困難であることを示した ${ }^{3)}$. さらに速度分布 の考察から, 伊藤と同一の無次元数 $R e^{*}$ 扤よび管摩擦係数を導い た。伊藤が示したように, この両者の関係は近似的にニニートン 流体のそれらの関係と同一になる。また，乱流に抢ける摩擦損失 を混合距離理論を用いて解析した結果, ニュートン流体に打ける Kármán-Prandtl の式と同形の式を得た ${ }^{32}$.

さて工学的に重要な流れの場の解析に対しては, 三次元構成方 程式が必要である。単純ずり流動に打ける純粘性非ニュートン流 体の構成方程式は，いくつか提案されているが，工学的には実験 結柴をかなり良く表現できれば, 若干の矛盾があっても, 解析的 に処理し易い式が望ましい，そこで最も簡単な 2 個の物質定数を 含をべき乘則モデルを取り上げ，これを三次元化してべき乗則流 休の運動方程式を導いた ${ }^{4)}$. この方程式は, べき指数 $n=1$ と置 けば, ニュートン流体に対する Navier-Stokes の方程式となるが, かなり複雑なので一般的には解析的に処理し難い，そこで実用的 に重要と考えられる慣性項が無視できる遅い流れに対して, 粘性 による散逸エネルギーを最小にする速度分布は運動万程式を満足 する，といら変分原理が成立することを示した．として球の抗力 の近似式を求めた ${ }^{4)}$. この変分原理は, もっと一般的な形をるつ 非ニュートン流体に拡張され，散逸エネルギー最小とい弓解釈は， べき乗則流体以外の純粘性非ニュートン流体に対しては成立しな いことが示されている5,6).さらに球の抗力についても, より精 密な解が多くの人々によって得られている. Bingham 流体に対 する変分原理は吉岡ら 求められている. 
ベき乗則流体および Bingham 流体の管内流熱伝達の解析およ び実験は，平办8,99によって行われたが，一般的には，これらの 流体に対する熱伝達の相似則は確立されているとは言えなかった。 そこで篗者は基礎方程式系を無次元化することによって，べき乘 則流体と Bingham 流体に対する熱伝達の相似則を誘導した ${ }^{10)}$. また, 細管粘度計などに関連して重要となる助走区間の流れ ${ }^{11)}$, 执よび鋭いかどの入日を持つ場合に执けるクリープ流れの入口損 失 ${ }^{12)}$ について解析した，前者は壁面に沿って発達する境界層流れ に対して運動量積分方程式を適用して, 助走区間の長さ和よび圧 力損失を解析的に求めた. 後者は入口部分の流れを二つの領域に 分けて，それぞれの部分に括ける速度分布を適当に仮定し散逸工 ネルギーを計算して入口損失を近似的に求めた。

さてニュートン流体の速い流れ，すなわち Reynolds 数の大き い流れの解析には，境界層理論が大きな力を持っている，筆者は べき乖則流体の流れにも Reynolds 数が大きければ境界層論的取 り报いが可能であることを示し, かつ境界層厚さのオーダーを表 す式を提示した。ささらに変分的手法を用いて，円管内助走区間の 流れを境界層論的取り报いにより解析した ${ }^{13)}$. 注ぼ同時期にべき 乗則流体の速い流れに対して Schowalter ${ }^{14)}$ が相似解の存在条件 を明らかにし，Acrivos $5^{15}$ が平板に沿う境界層流れを解析して 摩擦抗力を求めている. ところで, 非ニュートン流体の輸送に際 して使用される遠心ポンプその他の回転機器に抒いて, その動力 推定に回転门板の摩擦抵抗を知ることが必要である. そこで筆者 は，回転归板まわりに生じる境界層がそれぞれ層流，乱流の場合 について解析し, 摩擦抵抗を求めた ${ }^{16)}$.

\section{3. 粘弾性流体の流れ}

\section{$3 \cdot 1$ 高分子融液および濃厚溶液の流れ}

1951年頃から高分子融液の粘弾性的流動を研究していた荒斗定 吉氏 (現慶応義塾大学名誉教授) と篗者之は, 研究室が近かった ので拓互いによく研究の話をしたが，氏の研究の中で师管押出法 に怙ける管長補正 ${ }^{17}$ に興味を持ち，これに関連した研究 ${ }^{18}$ を発表 した，これが筆者の粘弾性流体の流動に関する最初の研究である. 粘性の大きい粘弾性流体が容器から短い細管に流入する場合, 助 走区間は極めて短く，管内で失われる卧力損失に比較して管入口 の付加的な圧力降下が無視できなくなり，管長の補正をしなけれ ばならなくなる，この管長補正係数は大きい值を持つ上に，見掛 けずり速度の增加関数になることが Bagley ${ }^{19}$, 荒井ら ${ }^{17}$ によっ て詳細に実験的に調べられ，補正係数を実験的に求める方法も提 示されている，筆者はこの問題を組合せモデル（弾性諭から得ら れる応力とひずみの関係と，非ニュートン粘性に関するべき乘則 を組合せた力学的モデル）を用いて，以前に行ったと同様なエネ ルギー論的手法で解析を行い, 補正係数が見掛けずり速度の関数 として表される近似式を導いた。

1959年頃からウィスコンシン大学のR.B. Bird教授と文通があ り, その後 Bird 教授が京都大学拈よび名古屋大学にフルブラィ 卜交換教授として来日されている間, 何度か扣会いし留学したい 希望を伝えた。そと結果, 1963年 9 月から 1 年間 Bird 教授のと ころで研究することになった．この当時，Bird 教授の研究室に は多くの大学院生が括り, 工学上重要な流れ塨の解析, 純粘性流 体技よび粘弾性流体の現象論的な構成方程式の誘導ならびにそれ らの検証のための解析, 実験を行っていた。 また J.D. Ferry 教
授の研究室のメンバー，その他のレオロジー研究者らとかなりひ んぱんに研究発表会を開催していた。筆者の仕事は主として解析 的研究であったが，Bird 教授は汪とんど何も束縛せず，かなり 自分勝手なことをやらせて戴き感謝すると共に申訳なく思ってい る. しかしこの 1 年間は, 多くのレオロジー研究者と会うことが でき非常に有意義であった，帰国後，留学中の研究結果を整理し て発表した．その一つは粘弹性流体の门管内層流助走区間内の流 れの問題である。すなわち，この流れを組合せモデルを用いて解 析し，压力損失に及ぼす弾性の効果を近似的に明らかにした ${ }^{20)}$. ところで1963年頃から, 東京都立大学工学部の加藤宏氏（現東京 都立大学教授) が粘弾性流体の研密に来て执られた。 そこで Maxwell \& Scalora ${ }^{21)}$ にって開発された法線心力効果を利用す る粘弾性ポンプ（あるいはねじなし押出機）の性能解析を研究対 象として取り上げ, これを解析的, 実験的に詳細に調べた22,23). ただしこのポンプ (押出機) は, 狭い㭞間の中で流体をずり流動 させるので混練效果は極めて良いが，法線応力効果を利用するた め押出圧力は低く, 実用上は普通の押出機と併用するのが良いか も知れない。

1965年頃より大学院生が急激に增加し, 筆者らの研究室にもレ オロジー関係で, 小林東和君（現三菱レイヨン株式会社中央研究 所), 長谷川富市君 (現新潟大学教授), 白樫正高君 (現長岡技術 科学大学助教授) らが在学していた. 1962年 Sakiadis²) は, 円管 内流動を利用して第 1 扣よび第 2 法線応力差を求める興味ある方 法を発表した。彼はポリビニールアルコール水溶液を用いて実験 を行ったが, その結果は第 2 法線応力差の值が第 1 法線応力差の 値の約70\%という，他の研究者の結果には見られない大きな值と

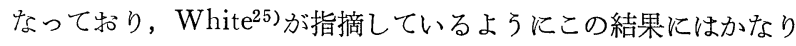
疑問がある. そこで小林と共にこの問題を調べて見ることにし た ${ }^{26)}$. まず法線応力差を求める際に必要となる境界条件, 扣よび 管より流出するジェットの挙動が，法線応力差に及ぼす影響を解 析的に検討し, 次いでヒドロキシェチルセルロース (HEC-WP 4400）の $3 \%$ 水溶液を用いて実験を行った. それらの結果として, Sakiadis の方法では第 2 法線灾力差を求めることができないこと, 並びに第 1 法線応力差の值は管出口の圧力に大きく依存すること を明らかにした。ささらに管出口付近の压力は, 流量のある值のと ころで極大値を持ち，それより流量が増加すると逆に圧力が低下 するという異常現象を見いだした. 一方, これまで粘弾性流体の 助走区間に関する実験的研究は注とんど行われていなかったので, 小林と共に助走区間内に括ける圧力降下を実験的に検討すること にした ${ }^{27)}$. 使用流体はニュートン流体としてタービン油, 純粘性 非ニュートン流体としてポリエチレンオキシド (PEO) $2 \%$ 水溶 液, 粘弾性流体として HEC-WP4400 の1.8\%水溶液拈よび Guar Gum $1.8 \%$ 水溶液を用いた. PEO 水溶液は一般的に粘弾性流体 であるが，高いずり速度を繰り返して受けると性質が変化し，粘 度が著しく減少すると共に法線灾力効果は全く失なわれる。そこ で測定を開始する前に PEO 水溶液を長時間循環し，性状が安定

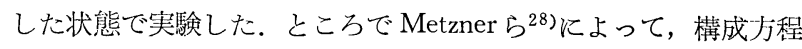
式を仮定せず応力成分で境界層方程式を表す方法が提案されてい るが，これを用いて助走区間内の流孔を非ニュートン粘性拉よび 法線応力効果を考慮して解析した. 実験的に得られた助走区間に 抢ける圧力降下を解析結果と比較すると, ニュートン流体, 純粘 性非ニュートン流体共両者はよく一致する. しかし粘弾性流体で 
は, 法線応力効果を考慮した解析結果でも実験値よりは小さい. そこでさらに比較的簡単な微分形構成方程式に, 記憶効果を表す パラメーターを導入したモデルを用いて解析した．その解析結果 はHEC 水溶液の実験值と一致したが, Guar Gum 水溶液に対し ては一致させることができなかった，Guar Gum 水溶液のよう に記憶効果の強い流体では，円管入口までの圧力降下が大きくな り, 容器内での流体の挙動を考虑しなければならない。また助走 区間内の流れの上うに，Reynolds 数が高く Lagrange 的に非定 常性の強い粘弾性流体の流動の解析に対しては, 權成方程式とし て積分形の方程式を用いる必要があるのかも知れない。

さて上述の助走区間内の流れなどと巽なって，一般に高分子融 液や濃厚溶液の工業上重要な流れは, Reynolds 数の小さい遅い 流れである場合が多い，工学的にはこのような場合の流れの解析 に便利な構成方程式を検討する必要がある.Langlois \& Rivlin ${ }^{29}$ は Rivlin-Ericksen モデルを用いてくさび形流路内のクリープ流 れを解析した。 その結果, 純粘性非ニュートン流体の狭李り流れ に执ける流線は, 頂点に向う放射線となるが, 粘弾性流体の場合 は，頂点付近で循環二次流れの生ずることを明らかにしている. また Kaloni ${ }^{30}$ も 6 定数 Oldroyd モデルを用いて解析し，同様に 二次流れの生ずることを示している. 小林と筆者 ${ }^{31}$ は, 工学的に 便利な構成方程式としてDenn モデルを取り上げ，これを用いて くさび形流路内のクリープ流れを解析し，一般的には放射状流れ が存在し得ないことを示した。しかし十分遅い流れで，かつ頂点 の極めて近くを除けば，近似的に放射状流れで近似できるとして， 摂動法を用いて流れの状態を調べた. Adams ら²ははホリスチ レンの $12 \%$ Aroclor 溶液を用いて，くさび形流路内の応力状態を 流動複屈折の方法を用いて実験的に求め, Coleman-Noll モデル による解析結果と比較している. 小林らの結果は Coleman-Noll モデルによる結果よりもやや実験值との一致が良いようである.

\section{$3 \cdot 2$ 不安定現象}

高分子融液や濃厚溶液を細管から押し出す場合, あるずり速度 以上になると，それまで滑らかに流出していた噴流が，その表面 に波形を生じ形状も不規則になる不安定現象が生じる．この現象 は一般的に melt fracture ${ }^{33}$ ) と呼ばれているが, 不安定現象と呼 ぶ方が適切の上らに思われる。 この不安定現象の発生は成形品の 機械的強度を低下させるので, その発生臨界ずり速度以下で成形 加工を行うことが必要である. このために生産量が制約されるこ とになり，工業的に重要な問題となっている．そこでこの現象を 解明するため多くの研究が行われているが, 現在までのところ末 だ不明の点が多い、筆者ら ${ }^{34}$ は, 高密度ポリエチレン拈よびポり プロピレンを用いて不安定現象の実験を行い, 二つの無次元数に よってこの現象を近似的に捉光ることができることを示した。し かし, 高分子融液によるよりも高分子濃厚溶液による寒験のうが 容易であり, 測定の精確さも期待でき, かつ流れの可視化が簡単 であるなどの利点を有するので, 筆者ら ${ }^{35}$ は $\mathrm{PEO}$ 水溶液を用い て不安定現象の詳細な実験的研究を行った. そして次元解析的考 察より，不安定現象を支配するパラメーターとしてDenn モデル を用いた場合, Reynolds 数, Weissenberg 数, Deborah 数, 幾 何学的因子, 二つの物質定数 (べき指数) の 6 個の無次元数によ り実験結果を整理し得ることを示し, これより不安定現象の発生 点を求める実験式を提示した。この不安定現象, すなわち細管出 口から不規則な流動を示寸現象を, 一次不安定現象と呼ぶことに
する．ところでこの一次不定定現象の発生臨界ずり速度の10倍位 のずり速度になると, 細管出口でBarus 効果を示さずほぼ管内径 と等しい太さで流出し, 出口からある距離に和いてふくらみ, か

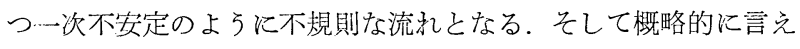
ば，この距離は時間と共に周期的に変化する，このような不安定 現象を二次不安定現象と名付ける。篗者ら ${ }^{36}$ は PEO 2.0，2.5\% 水溶液拈よびポリアクリルアミド (SEP) $3.5,4.0 \%$ 水溶液を用 いて二次不安定現象败関する実験容行い，出口からふくらむまで の距離の変化と管入口付近の圧力垐動の間には, 強い相関がある ことを明らかにしている．また進邦ら ${ }^{37}$ は，管出口付近の流速分 布が，十分に発達した定常流の流速分布と非常に異なることを， トレーサー法を用いて実験的に明らかにした。 そして管出口付近 の压力が流量増加に対して極大值を持つことを, この流速分布の 測定值を表す実験式とDenn モデルを用いて解析的に明確に示し た.

\section{$3 \cdot 3$ 希薄高分子溶液の流れ}

$\mathbf{3} \cdot \mathbf{3} \cdot \mathbf{1}$ 抗力の低減 $\mathrm{Toms}^{38}$ は 1948年オランダで開催され た第 1 回国際レオロジー会議に括いて, ポりメタクリル酸メチル ・モノクロールベンゼン溶液の管内流に拈ける乱流摩擦損失が, 溶媒であるモノクロールベンゼンのそれより低減するという結果 を発表した，これが希薄高分子溶液において乱流摩擦抵抗が減少 するという現象の最初の研究報告と言われ, 以後この異常現象を Toms 効果と呼九でいる. 1963年, 第 4 回国際レオロジー会議で Fabula ${ }^{39}$ )が 11〜600ppm の希薄なボリエチレンオキシド水溶液を 用いて円管内乱流の実験を行い，管縻擦損失が著しく減少するこ とを発表した。このように少量の水溶性添加物により, 摩擦抗力 の著しい減少が得られるといら事実は多くの流体工学者の注目を 浴び, 以後多数の研究者によって実絤が行われるようになった. この当時 (1963〜1964年), 在米していた筆者はこの閆題に與味 を持ち理論的な考察を行い，その結琴を Bird 教授主催のセミナ 一で発表した，一般に乱流に和いては，流体粒子の混合運動が生 じるため運動量輸送による Reynolds 応力, すなわち乱流粘性が 分子粘性に加わるため, 摩擦損失が層流の場合より大きくなる. しかし希薄高分子溶液では, 法線応力効果のため流体粒子の混合 運動が制約を受け, その結果 Reynolds 応力が減少し, 摩擦抗力 が低減するという考方方である. 希薄高分子溶液のレオロジー的 挙動を表す構成方程式として, 組合せモデルを用いての上述の考 え方に基づく円管内乱流住する摩擦抗力の解析結果は, ニュー トン流体に対する Kármán-Prandtl の式と, 純粘性非ニュートン 流体に対する Dodge-Metzner の式を特別の場合として含んでい る ${ }^{40)}$ 。 その後, 長谷川と共に HEC 水溶液を用いて種々の管径を 持つ管路に対して Reynolds 数, ずり速度を広範囲に変化させて Toms 効果の実験を行った。 その実駼結果は, 上述の解析的取り 报いを少し改良した結果によって良く整理できることを明らかに した ${ }^{41}$. ところで多くの研究者による, 希薄高分子溶液の層流か ら乱流们㲿ての管摩擦係数の実験結果を大別すると, 二つの形 に分けられる。 その一つは層流から乱流への移行過程がニュート ン流体と同様であり, 遷移領域に扣ける特異性はない形である。 他の一つは, 変った遷移現象で, 濃度が比較的高い場合や管径が 小さい場合に多く見られるようである。すなわち，Reynolds 数 に刘する管摩擦係数の線図に扣いて, Reynolds 数の增加と共に 層流管摩擦係数を表す線から徐々に上方にずれる準储領域と見ら 
れる領域を経て遷移が起こり，乱流に移行していく形で饬る．

この後者の遷移過程について, 長谷川ら ${ }^{42}$ は詳細な実験を行っ た。すなわち，遷移過程に括ける管摩擦損失を精度良く測定する と共に，細管より流出する噴流形状が，Reynolds 数の增加に対 して, ニュートン流体の場合には見られない特買な形状を示すこ とを見いだした。そしてこの貲流形状の変化と圧力変動ならびに 管摩擦損失の関連を調べ，それらの相関を明らかにした。これよ り噴流形状によって，遷移への移行過程を知ることができること を示した，また，準備領域に和ける擤乱流をDenn モデルを用い て近似的に解析し，実験結果と一致する管摩擦係数の式を導い $た^{42}$. この頃, 大学院生として持丸義弘君（垷東京工業大学助教 授）が筆者らの研究室に入り，レオロジー関係の研究を行うこと になった，そこで管内流から離れてて，流体輸送に使用される遠心 ポンプなどの動力低減に関連して重要となる, 回転门板の乱流摩 擦抵抗に関するToms 效果を, 境界層論的手法を用いて解析的に 調ベた ${ }^{43)}$.

$3 \cdot 3 \cdot 2$ 種々の流れの解析と計測 希薄高分子溶液の物体ま わりの流れについて，いくつかの研究を持丸と共に行った。その 一つは, 層流から乱流への遷移過程の機棈解明浭要となる, 平 板に沼う層流境界層の安定性の問題である。ニュートン流体につ いては, Tollmien, Schlichting, Lin, Shen らにより線形安定理 論を用いて中叿安定曲線が計算され，その作しさが実験的に検証 されている，そこで希薄高分子溶液の層流安定性を調べるために， 構成方程式として Denn モデルを用い，微小䚌乱の増幅，減衰を 支配する線形方程式を導き，これより平板に沿万層流境界層に対 する中立安定曲線を求めた。 その結果, 流体の弾性は流れを不安 定化させ, 非ニュートン粘性は流れを安定化させることを明らか にした ${ }^{44)}$. 次に希薄高分子溶液の一様流中に置かれた円柱周りの 二次元層流に扣ける速度場, 温度場, 強制対流熱伝達を解析的に 調べた ${ }^{45)}$. 円柱周りの二次元流は各種の萟伝湭や，速度測定に対 する熱線流速計の使用の可否などに関連する基本的問題であるが， いままで余り研究されていないので調べてみることにした，解析 は低 Reynolds 数, 中程度の Reynolds 数掞よび高 Reynolds 数 の各場合について行った. その結果, 抗力係数が溶媒のそれより 增加してはく離を伴う流れでは，はく離点が後ナに移動する。ま た，熱線流速計の場合のように比較的低 Reynolds 数では, 熱伝 達が減少するが, 高 Reynolds 数の場合には余り大きな変化はな いことなどが明らかになった。

さて, Toms 効果を示す希薄高分子溶液の流動の内部機構を明 らかにするためには, 流れの可視化, 流速測定, 速度変動の測定 などが必要となる．ピトー管によって流速湘定を行う場合には， ニュートン流体の場合と異なり，探子そ5入の影響の大きいこと が, Metzner ら ${ }^{46)}$, その他によって定性的に予測されている。 そ こでこの問題を解析的, 実験的に検討し, 溶液の粘弾性的挙動が ピトー管特性に与える影響を明らかにした ${ }^{47)}$.ところで高分子濃 厚溶液の法線応力差は, レオゴニオメーター, 流動複屈折などの 万法によって測定可能であるが, 粘弾性挙動が著しくは現れない 希薄高分子溶液の場合には, これらの方法は検出精度などの点で 使用が困難となる，そこで问管より流出するジェットを利用する ジェットスラスト法48)などが使用されている．持丸ら ${ }^{49,50)}$ 执よび 長谷川 ${ }^{51)}$ は, 流出ジェットの細管に及ぼす反力を利用する方法を 用い, ppm オーダーの種々の希薄高分子溶液の第 1 法線応力差
の測定を可能にする新たな㥶験装置を開発し，その測定原理を明 らかにすると共に, 測定に際して生ずる問題点などを, 実験的, 解析的に詳細に調べた。一方，水素気泡法による流れの可視化を 行了場合, 細線の後流を詳細に知る必要がある。希薄高分子溶液 中では, その粘弾性効果のため, 後流特性が著しく変化すること が指摘されている，そこでこの後流特性を解析的に調べ, 水素気 泡法を使用する際の問題点を解明している ${ }^{52}$.

\section{4. おわりに}

以上が非ニュートン流体の流動に関して筆者の行ってきた研究 概要であるが，かなりばらばらで統一的見解がない上うに思われ るかも知れない, しかし筆者としては, 流動, 櫬拌, 輸送, 混合, 伝熱, 成形加工などに関連して, これまで主として経験的, 定性 的に処理されてきた非ニュートン流体の流れ挙動の解明に, レオ ロジー的, 並びに流体力学的手法を取り入れて, これらに対して 一貫した定量的方法を提供する, 非ニュートン流体力学の確立を 目的としたわけであるが，篗者の能力不足のためほとんど成果は 挙がらなかった。しかし，レオロジーは学問分野として独立以来 60年程度の歳月しか経て扔らず，その上，対象物質が多岐にわた ると共にそれらは極めて複雑な力学的挙動を示すため, 手法確立 にはまだかなりの時間がかかるかも知れない，今後は分子論的な 基礎研究との融合をはかるなど，広い角度からの研究により，一 日も早く有力な手法となるべき非ニュートン流体力学の確立され ることを希望するものである。

\section{文献}

1）富田幸雄, 日本レオロジー学会誌，14，1（1986）.

2）伊藤四郎, “塑性流体の流れ”, 日刊工業 (1957).

3）富田幸雄, 日本機械学会論文集，24-141，288（1958）; Bull. JSME, 2-5, 10 (1959).

4）富田幸雄, 日本機械学会諭文集, 25-149, 17 (1959); Bull. JSME, 2-7, 469 (1959).

5) Bird, R.B., Phys. Fluids, 3, 539 (1960).

6) Johnson, M.W., Phys. Fluids, 3, 871 (1960) ; Trans. Soc. Rheol., 5, 9 (1961).

7) 吉岡直哉, 足立毅太郎, 石村秀一, 化学工学, $35(10)$, 1144 (1971).

8) 平井英二, 化学工学, 20(8), 440 (1956).

9) 平井英二, 化学工学, 21(1), 17 (1957).

10）富田幸雄, 化学工学, 23(2), 66 (1959).

11）富田幸雄, 化学工学, 23(8), 525 (1959).

12）富田幸雄, 日本機械学会諭文集， 25-157，938（1959）.

13）富田幸雄, 日本機械学会論文集， 26-165，675（1960）; Bull. JSME, 4-13, 77 (1961).

14) Schowalter, W.R., AIChE J., 6, 24 (1960).

15) Acrivos, A., M.J. Shah and E.E. Petersen, AIChE J., 6, 312 (1960).

16）富田幸雄, 日本機械学会論文集，27-174，184（1961）; Bull. JSME, 4-16, 671 (1961).

17）荒井定吉，ゴム協会誌，30(12)，993（1957).

18）富田幸雄, 日本機械学会論文集，27-183，1700（1961）; Bull. JSME, 5-19, 443 (1962). 
19) Bagley, E.B., J. Appl. Phys., 28, 624 (1957).

20）富田幸雄, 山根隆一郎, 日本機械学会論文集, 32-234, 250 (1966) ; Bull. JSME, 9-36, 730 (1966).

21) Maxwell, B. and A. Scalora, Mod. Plast., 37(2), 107 (1959).

22）富田幸雄, 加藤 宏, 日本機械学会論文集, 32-241，1409 (1966) ; Bull. JSME, 10-39, 507 (1967).

23）加藤 宏，日本機械学会論文集，32-241，1409（1966）; Bull. JS ME, 10-39, 516 (1967).

24) Sakiadis, B.C., AIChE J., 8, 317 (1962).

25) White, J.L., AIChE J., 9, 559 (1963).

26) Tomita, Y. and T. Kobayashi, Proc. 5th. Inter. Congr. Rheol., 4, 365, Japan (1970).

27）小林東和, 富田幸雄, 日本機械学会論文集, 36-287, 1109 (1970) ; Bull. JSME, 14-69, 208 (1971).

28) Metzner, A.B. and J.L. White, AIChE J., 11, 324, 989 (1965).

29) Langlois, W.E. and R.S. Rivlin, Technical Report 3, Army Ordnance R \& D Project TB2-0001, Brown University, Providence, R.I. (1959).

30) Kaloni, P.N., J. Phys. Soc. Japan, 20, 132, 610 (1965).

31）小林東和, 富田幸雄, 日本機械学会論文集, 37-298, 1187 (1971) ; Bull. JSME, 15-80, 236 (1972).

32) Adams, E.B., J.C. Whitehead and D.C. Bogue, AIChE $J .$, 11, 1026 (1965).

33) Tordella, J.P., J. Appl. Phys., 27, 454 (1956).

34）富田幸雄, 上屋 健, 日本機珹学会論文集, 29-198, 245 (1963) ; Bull. JSME, 6-24, 709 (1963).

35) Tomita, Y. and T. Shimbo, Appl. Polym. Symp., 20, 137 (1973).

36) Tomita, Y., T. Shimbo and Y. Ishibashi, J. Non-New- tonian Fluid Mech., 5, 497 (1979).

37）進邦紀夫, 富田幸雄, 横山俊雄, 日本レオロジー学会誌, 11, 142 (1983).

38) Toms, B.A., Proc. Inter. Congr. Rheol., II, 135, North Holland Publ. Co., Amsterdam (1949).

39) Fabula, A.G., 4th Inter. Congr. Rheol., Brown Univ. (1963).

40）富田幸雄， 日本機械学会論文集， 32-234，242（1966）; Bull. JSME, 9-36, 730 (1966).

41）長谷川富市, 富田幸雄, 日木機械学会諭文集, 35-274, 1277 (1969).

42）長谷川富市, 富田幸雄, 日本機械学会諭文集, 39-321, 1542 (1973) ; Bull. JSME, 17-103, 73 (1974).

43）持丸義弘, 富田幸雄, 日本機械学会論文集, 38-310, 1416 (1972) ; Bull. JSME, 16-92, 291 (1973).

44）持丸義弘, 富田幸雄, 日本機械学会論文集, 39-319, 869 (1973) ; Bull. JSME, 16-101, 1683 (1973).

45）持丸義弘, 富田幸雄, 日本機械学会論文集，40-329， 217 (1974) ; Bull. JSME, 17-111, 1172 (1974).

46) Metzner, A.B. and G. Astarita, AIChE J., 13, 550 (1967).

47）持丸義弘, 富田幸雄, 日本機㣝学会論文集, 40-332, 1013 (1974) ; Bull. JSME, 17-114, 1594 (1974).

48) Oliver, D.R., Canad. J. Chem. Eng., 44, 100 (1966).

49）持丸義弘, 富田幸雄, 長谷川富市, 日本機械学会論文集, 42-354, 564 (1976).

50) Tomita, Y. and Y. Mocliimaru, J. Non-Newtonian Fluid Mech., 7, 237 (1980).

51）長谷川富市，日本機械学会論文集，44-381，1606 (1978).

52）持丸義弘, 富田幸雄, 日本機械学会論文集， 44-377， 101 (1978); Bull. JSME, 21-159, 1364 (1978). 